\title{
Penerapan Kegiatan Sentra Seni pada Pembelajaran di PAUD
}

\author{
${ }^{1}$ Evy Fitria, ${ }^{2}$ Titi Rachmi, ${ }^{3}$ Angger Prima Widiasih \\ 1,2,3Program Studi Pendidikan Guru Pendidikan Anak Usia Dini; Fakultas \\ Keguruan Dan Ilmu Pendidikan; Universitas Muhammadiyah Tangerang \\ 1evifitria7@gmail.com, ${ }^{2}$ titirachmi1985@gmail.com, ${ }^{3}$ widiasih.angger@gmail.com
}

\begin{abstract}
Abstrak
Penelitian ini dilatar belakangi dari rasa ingin tahu peneliti terhadap sekolahsekolah yang telah melaksanakan pendekatan pembelajaran berbasis sentra, dimana anak-anak belajar melalui bermain disentra yang sudah di sediakan oleh sekolah, salah satunya yaitu sentra Seni. Peneliti ingin melihat bagaimana penerapan Sentra Seni dan melihat aspek perkembangan apa yang muncul saat anak melakukan Kegiatan di Sentra Seni. Tempat Penelitian ini adalah di RA AlMuhajirin Kec.Tangerang, Kota Tangerang Metode penelitian ini menggunakan Kualitatif deskriptif dengan Data yang diambil melalui pengamatan/ observasi dan wawancara kepada sumber di lapangan. Keabsahan data menggunakan triangulasi dengan berbagai sumber dan metode yang berbeda. Hasil penelitian menunjukkan bahwa penerapan kegiatan Sentra Seni dilakukan melalui 4 Tahapan Pijakan, yaitu Pijakan Penataan Lingkungan Main, Pijakan Sebelum Bermain dan Pijakan Sesudah Bermain. Kegiatan main di Sentra Seni terlihat menggunakan Projek kerja Kelompok namun juga terkadang menggunakan projek kerja mandiri. Saat anak-anak Melakukan Kegiatan di Sentra Seni Terlihat Aspek perkembangan yang Dominan muncul adalah:bahasa anak,Kognitif, seni, Sosial emosional anak serta Kemandirian anak
\end{abstract}

Kata kunci : Sentra Seni, Pembelajaran di PAUD

\section{Pengantar}

Pembelajaran sentra merupakan pendekatan untuk menempatkan dunia nyata ke kelas dan menghubungkan pengetahuan anak-anak dengan kehidupan sehari-hari, pendekatan Sentra bisa memaksimalkan semua kecerdasan. Menurut Mutiah (2010:133) "model pembelajaran sentra adalah model pembelajaran yang dalam pembelajarannya dilakukan di dalam lingkaran (Circle times) dan sentra 
"Ceria"

\section{Jurnal Program Studi Pendidikan Anak Usia Dini}

bermain Ada tiga fungsi utama dalam metode BCCT. Fungsi tersebut adalah dalam rangka melejitkan kecerdasan anak, penanaman nilai-nilai dasar, dan pengembangan kemampuan dasar sehingga anak menjadi pembelajar aktif (Dirjen paud, 2006:2)., Allen dan Marots (2010 : 148) mengungkapkan bahwa anak usia dini menghabiskan banyak waktu dan perhatiannya pada praktik dan penguasaan keterampilan disemua bidang pengembangan. Terdapat 6 aspek perkembangan anak yaitu : kognitif, fisik motorik, bahasa, sosi-emosional, moral dan seni. Semuanya harus berkembang optimal sedini mungkin melalui stimulasi lingkungan. Salah satu adalah dengan kegiatan yang membebaskan anak untuk berkarya baik coretan maupun hasil karya lainnya. Hal penting dalam pelaksanaan model pembelajaran Sentra ini, yaitu: intensitas bermain dan densitas bermain. Intensitas bermain adalah waktu yang dibutuhkan untuk pengalaman anak dalam 3 jenis main disepanjang hari dan sepanjang tahun, sedangkan densitas bermain adalah berbagai cara bermain pada setiap jenis main yang disediakan untuk mendukung pengalaman anak (Sujiono, 2009:218). Sejalan dengan Marjorie, et.al, (2007:112) yang menyatakan bahwa melalui sentra anak anak menjadi siap dan merespon untuk menemukan sesuatu yang anak butuhkan.

Dalam pembelajaran Sentra terdapat 7 sentra kegiatan, yaitu salah satunya adalah sentra Seni. Sentra Seni merupakan Area kegiatan pembelajaran dimana anak-anak melakukan aktivitas dengan membuat karya. Berdasarkan hasil penelitian Lestarini (2013) penerapan model pembelajaran Sentra /Beyond Centers and Circle Time (BCCT) di TK Bumi Gora dapat meningkatkan minat dan aktivitas belajar anak dengan baik. Sejalan dengan hal tersebut, Wahyuningsih dan Slamet (2015) TK Al-Farisi 2 Yogyakarta dapat menggunakan nilai-nilai kearifan lokal untuk mengembangkan kemampuan sosial pada anak usia dini melalui BCCT yang telah dirancang khusus. Penelitian lain yang dilakukan oleh Fitria (2014) SD

Kelas Awal di SD Jayawinta Kunciran, Kota Tangerang menjelaskan bahwa pembelajaran sentra mengembangkan 18 sikap yang muncul dalam pembelajaran 
"Ceria"

Jurnal Program Studi Pendidikan Anak Usia Dini

sentra, namun sikap mutu, hormat dan jujur, insyaallah sudah mewakili sikap sikap yang lain. Menurut hasil Penelitian yang dilakukan oleh Ulfa, dkk, di TK MuJahidin II Pontianak Timur menemukan bahwa Masih Kurangnya media yang digunakan Guru dalam kegiatan di sentra seni.

Untuk itu Pentingnya sebuah pembelajaran yang disetting oleh guru dalam setiap kegiatan belajar anak adalah melalui bermain. Karena hakekatnya sebuah Pembelajaran adalah memanusiakan manusia menjadi manusia yang berbudi dan memiliki karakter sesuai dengan tujuan Pendidikan yang tercantum dalam UUD 1945. PAUD merupakan Peletak dan Pencetak Generasi Selanjutnya, sehingga Perlu kiranya pembelajaran yang didapat oleh anak Usia Dini adalah menyenangkan dan mengembangkan Karkater anak. hal ini senada dengan Fitria (2014) Apabila sekolah memberikan kegiatan pembelajaran yang sesuai tumbuh kembang anak, yang menyenangkan dan tidak membosankan yang tidak mendorong kemampuan kognitifnya saja, melainkan menyentuh ranah Afeksinya, maka akan muncul dengan sendirinya sikap-sikap anak yang membanggakan sebagai implikasi dari sebuah model pembelajaran yang diberikan oleh sekolah. Karena sekolah merupakan salah satu kunci membentuk karakter.

\section{Metode}

Penelitian ini menggunakan jenis penelitian kualitatif dengan rancangan studi kasus. Kehadiran peneliti sangat dibutuhkan dalam penelitian ini karena pengumpul data dan instrumen utama penelitian ini adalah peneliti itu sendiri. David Williams dalam Maleong(2011:5)mengemukakan bahwa penelitian Kualitatif adalah pengumpulan data pada suatu latar alamiah, dengan menggunakan metode alamiah, dan dilakukan oleh seorang atau peneliti yang tertarik secara alamiah.Bogdan dan Taylor dalam Moleong (2011:4) mengemukakan bahwa metode kualitatif merupakan prosedur penelitian yang menghasilkan data deskriptif berupa kata-kata tertulis maupun lisan dari orang- 
"Ceria"

Jurnal Program Studi Pendidikan Anak Usia Dini

orang dan perilaku yang diamati. Pengambilan data dilakukan melalui pengamatan atau observasi, wawancara dan dokumentasi di RA Al-Muhajirin Kec. Tangerang Kota Tangerang. Teknik analisa data yang dipakai dalam penelitian ini adalah anlisa model Milles dan Huberman, yakni aktivitas dalam analisis data kualitatif dilakukan secara interaktif dan berlangsung secara terus menerus sampai tuntas, sehingga datanya sudah jenuh. Aktivitas dalam analisis data yaitu : reduction, display, dan conclusion drawing verification (Sugiyono. 2012 : 337).

\section{Hasil dan Pembahasan}

Kegiatan Sentra Seni dilakukan melalui 4 pijakan, yaitu : 1) Pijakan penataan Lingkungan Main, pada Pijakan ini guru menata berbagai alat main dan media yang akan digunakan oleh anak. Media di sentra seni yang di letakkan oleh guru diletakkan sesuai dengan apa yang sudah tertuang dalam RKH. 2) Pijakan saat Bermain, Pada Pijakan ini, Guru mengajak anak untuk duduk melingkar membahas Tema dan topik pembahasan. Pada pijakan ini pula guru menjelaskan kegiatan main dan aturan main yang akan anak-anak lakukan di sentra seni. 3)Pijakan Saat Bermain, Pada pijakan ini anak-anak memasuki area sentra seni dan melakukan kegiatan. 4) Pijakan Setelah Bermain, anak dan guru duduk melingkar, guru terlihat menanyakan kembali(recalling) kegiatan anak di sentra seni. Anak-anak secara satu persatu menceritakan pengalaman mainnya di sentra seni dan teman- teman lainnya mendengarkannya.

Kegiatan yang dilakukan di sentra seni terlihat selalu mengajak anak untuk dapat aktif dan kreatif dalam menghasilkan suatu karya. Karya yang dibuat oleh anak terlihat sering menggunakan Projek kerja Bersama, dimana anak-anak menyelesaian sebuah karya dengan Berkelompok 2-4 orang. Namun terkadang kegiatan di sentra seni ini di setting oleh guru dengan tanpa projek, namun guru mensetting densitas main(banyaknya kegiatan main) dan Anak-anak terlihat berpindah dari satu kegiatan ke kegiatan lainnya yang sudah di setting oleh guru. 
"Ceria"

Jurnal Program Studi Pendidikan Anak Usia Dini

Kegiatan di Sentra seni yang dilakukan diantaranya: menyusun, menggunting, menempel, melipat mewarnai, menggambar, dan media yang sering digunakan adalah :Lem, Pensil Warna, Origami, Barang-barang bekas,Kardus, Gunting. Semua Media disusun diarea sentra seni disaat Pijakan penataan lingkungan Main, sebelum anak-anak hadir dikelas. Semua Kegiatan tersusun jelas dalam Rencana Kegiatan Harian(RKH) yang telah dibuat oleh guru.

Dalam Kegiatan di Sentra Seni, Peneliti melihat Aspek perkembangan Bahasa,Kognitif, sosio-emesional anak, seni dan Kemandirian merupakan aspek perkembangan yang terlihat jelas muncul dalam diri anak. Aspek perkembangan Bahasa, terlihat pada saat anak menceritakan pengalaman main mereka setelah kegiatan. Semua anak menceritakan pengalaman main mereka dengan bahasa mereka dan gaya mereka masing-masing. Terlihat semua anak mengungkapkan perasaannya walau ada yang menceritakan dengan bahasa yang singkat dan lambat. Aspek Perkembangan Kognitif, dikegiatan sentra anak melakukan berbagai kegiatan, menyusun rumah, membuat baju, membuat ruangan dalam rumah. Semua kegiatan tersebut membutuhkan kemampuan kognitif anak,sehingga semua karya dapat dibentuk sesuai dengan ukuran dan fungsinya. Aspek Perkembangan Sosio-emosional, Kegiatan yang disetting oleh guru di sentra seni banyak menggunakan projek kerja bersama, dimana anak menyelesaiakn kegiatan membuat sebuah hasil karya seni bersama-sama. Pada kegiatan ini terlihat anak belajar untuk bisa menyelesaiakn pekerjaannya secara bersama-sama. Aspek Kemandirian, di di Sentra seni, anak-anak terlihat belajar mandiri, dan merapihkan peralatan nya secara mandiri.Aspek Seni, Pada Kegiatan Seni anak-anak terlihat mampu memadukan warna, mampu menyusun agar karya yang dibuat terlihat indah, walau masih ada yang membutuhkan bantuan dari guru dan temannnya, namun kegiatan di sentra seni ini memunculkan perkembangan aspek seni dalam diri anak.

Hasil penelitian menunjukkan bahwa kegiatan Kegiatan disentra seni, telah disusun dalam RKH yang dibuat oleh guru, yang didalammya memuat tentang 
"Ceria"

\section{Jurnal Program Studi Pendidikan Anak Usia Dini}

langkah-langkah kegaiatan di sentra seni dalam 4 Pijakan. Hal ini sejalan dengan pendapat Moeslchatoen (2004) yang menjelaskan bahwa rencana kegiatan bermain (RPPH) meliputi penentuan tujuan kegiatan bermain, macam kegiatan bermain, tempat dan ruang bermain, bahan dan peralatan bermain, dan urutan langkah bermain. Dalam dalam aktivitas di sentra seni terlihat kemampuan bahasa anak,Kognitif, seni,Sosial emosional anak serta Kemandirian anak sangat kental terihat dalam diri anak. Kegiatan di sentra Seni penuh dengan kegiatan bermain dalam membuat karya bersama maupun mandiri yang menyenangkan bagi anak, hal ini sejalan dengan pendapat Yanuarita (2014) yang mengungkapkan bahwa dalam suasana bermain kreatif, anak memperoleh kesempatan yang luas untuk melakukan eksplorasi guna memenuhi rasa ingintahunya, anak bebas mengekspresikan gagasannya melalui khalayan, drama, bermain konstruktif, dan sebagainya. Sehingga dengan mengekspresikan idenya anak akan lebih cerdas dalam segala hal, Kegiatan di Sentra Seni juga merupakan kegiatan yang mengajak untuk bebas mengeluarkan imajinasinya dan ekspresi melalui Hasil Karya Seni Anak.

\section{Kesimpulan}

Berdasarkan hasil analisis penelitian yang ditemukan dilapangan, menunjukkan bahwa Kegiatan Kegiatan di Sentra Seni dilakukan melalui 4 Pijakan yang telah direncanakan oleh guru dalam RKH. Hasil temuan juga menyimpulkan bahwa bahasa anak,Kognitif, seni,Sosial emosional anak serta Kemandirian anak terlihat berkembang dengan baik. Dalam Kegiatan di Sentra Seni anak-anak banyak melakukan kegiatan membuat hasil karya seni baik individu maupun projek kelompok. Guru sebagai Fasilitator dan Motivator anak disaat anak melakukan merupakan scaffolding (dukungan) yang sangat membantu anak dalam mencapai tugas- tugas perkembangannya.

Penelitian tentang pendekatan Sentra pada Pembelajaran di PAUD sudah cukup popular saat disosialisasikan oleh DIrjen PAUD pada tahun 2004, namun 
"Ceria"

Jurnal Program Studi Pendidikan Anak Usia Dini

masih rendah dalam penelitiannya mengenai penyebaran (difusi) penggunaan pembelajaran sentra ini. Untuk penelitian-penelitian yang akan datang, diharapkan dapat dilakukan penelitian tentang bagaimana difusi dari inovasi pmebelajaran berbasis Sentra ini dan bagaimana Analisis kebutuhan dalam pembelajaran Sentra maupun dalam setiap sentra, salah satunya sentra seni.

\section{Daftar Acuan}

Allen, K allen dan Lynn Marotz. 2010. Profile Perkembangan Anak Pra Kelahiran Hingga 12 Tahun. Penerjemah Valentino. Jakarta : Indeks.

Depdiknas. 2006. Petunjuk TeknisPenyelenggaraan PendidikanAnak Usia Dini (PAUD).

Fitria, Evy. Penerapan Model BCCT/Sentra dikelas 1. Jurnal PAUD UNJ,Vol.8 Edisi 1. 2014.

Lestarini, Yuniar. Penerapan BCCT/Sentra Dalam Meningkatkan Minat dan Aktivita Belajar. e-Journal PPs Pendidikan Ganesa. Vol.3. 2013

Marjorie, J. et all.2007. Developmentally Appropriate Curriculum.USA .

Moeslichatoen. (2004). Metode Pengajaran di Taman Kanak-Kanak. Jakarta: PT Rineka Cipta.

Moleong,Lexy J. 2011. Metodologi Penelitian Kualitatif (Edisi Revisi; Bandung: PT Rosda Karya.

Mutiah ,Diana. 2010. Psikologi Bermain Anak Usia Dini. Jakarta:Prenada Media.

Sugiyono. 2012. etode Penelitian Pendidikan Pendekatan Kuantitatif, kualitatif, dan R\&D . Bandung: Alfabeta.

Sujiono, YulianiNurani.Konsep Dasar Pendidikan ANak Usia Dini . Jakarta: Indeks. 2009.

Ulfa, Viza Novian.2011. Kemampuan Guru dalam Mengelola Sentra Seni. Jurnal Untan.ac.id.

Yanuarita, F. (2014). Rahasia Otak \& Kecerdasan Anak. Yogyakarta: Teranova Books. 